\title{
PENGARUH PENINGKATAN KREDIT BPR, PRODUK DOMESTIK REGIONAL BRUTO (PDRB) DAN TINGKAT PENGANGGURAN TERBUKA TERHADAP PENURUNAN TINGKAT KEMISKINAN
}

\author{
Tiara Fitri Rizkiyah ${ }^{1}$, Nunung Nurhayati ${ }^{2}$ \\ ${ }^{1,2}$ Universitas Wiralodra, Jln. Ir. H. Juanda Km 3, Indramayu, tiarafitririzkiyah17@gmail.com, \\ hajinunung.86@gmail.com
}

Diterima 20 Juli 2020, disetujui 18 Oktober 2020, diterbitkan 30 Oktober 2020

Pengutipan: Rizkiyah, T.F \& Nurhayati, N. (2020). Pengaruh Peningkatan Kredit BPR, Produk Domestik Regional Bruto (PDRB) dan Tingkat Pengangguran Terbuka Terhadap Penurunan Tingkat Kemiskinan. Gema Wiralodra, Vol 11, No 2, Hal 311-326, Oktober 2020

\begin{abstract}
ABSTRAK
Kemiskinan merupakan persoalan kompleks yang masih sulit terpecahkan hampir di setiap daerah di Indonesia. Tingkat kemiskinan ini dapat dipengaruhi oleh beberapa faktor diantaranya Pemberian Kredit oleh BPR, Produk Domestik Regional Bruto (PDRB), dan pengangguran terbuka. Oleh sebab itu, studi ini meneliti tentang bagaimanakah pengaruh peningkatan Kredit BPR, Peningkatan PDRB,dan Peningkatan tingkat Pengangguran Terbuka terhadap Penurunan tingkat kemiskinan di Provinsi Jawa Barat, dalam hal ini untuk seluruh kabupaten/kota di Jawa Barat tahun 2010-2016. Data yang digunakan dalam penelitian ini adalah data sekunder yang diperoleh dari Badan Pusat Statistik (BPS) Otoritas Jasa Keuangan (OJK), dan Bank Indonesia (BI). Sedangkan metode analisis yang digunakan dalam penelitian ini adalah metode analisis regresi linier panel data dengan bantuan Eviews 8.0 dengan Fixed Effect Model digunakan sebagai teknik analisis pada penelitian ini. Hasil penelitian menunjukkan bahwa (1) Peningkatan Kredit BPR berpengaruh signifikan pada taraf nyata 5\% dengan nilai probabilitas 0,0000 dan berhubungan negatif dengan nilai koefisien yang diperoleh sebesar -0144. (2) PDRB tidak berpengaruh signifikan pada taraf nyata 5\% dengan nilai probabilitas 0,1016 dan berhubungan negatif dengan nilai koefisien yang diperoleh sebesar -0,024. (3) Pengangguran berpengaruh signifikan pada taraf nyata 5\% dengan nilai probabilitas 0,0000 dan berhubungan positifldengan nilai koefisien yang di peroleh sebesar 0.137. Selanjutnya secara simultan bahwa Kredit BPR, PDRB dan pengangguran mempengaruhi tingkat kemiskinan di provinsi Jawa Barat sebesar 43,3\%. Sedangkan sisanya dipengaruhi faktor lainnya.

Kata Kunci: Penurunan Tingkat Kemiskinan, peningkatan kredit BPR, Peningkatan PDRB, Peningkatan Tingkat Pengangguran Terbuka
\end{abstract}

\begin{abstract}
Poverty is a complex problem that is still difficult to solve in almost every region in Indonesia. The level of poverty can be obtained by several factors, including the provision of credit by BPR, Gross Regional Domestic Product (PDRB), and open unemployment. Therefore, this study examines how an increase in BPR credit, an increase in GDP, and an increase in open unemployment to a reduction in the poverty rate in West Java Province, in this case for all districts/cities in West Java in 2010-2016. The data used in this study is secondary data obtained from the Central Statistics Agency (BPS), the Financial Services Authority (OJK), and Bank Indonesia (BI). While the method of analysis used in this research is a linear regression analysis of panel data with the help of Eviews 8.0 with the Fixed Effect Model which is used as an analysis technique in this study. The results showed that (1) the increase in BPR credit had a significant effect on the real level of $5 \%$ with a probability value of 0.0000 and was negatively related to the coefficient value obtained -0144. (2) GRDP has no significant
\end{abstract}


effect in 5\% real cases with a probability value of 0.1016 and negatively related to the coefficient value obtained of -0.024. (3) Unemployment has a significant effect on the real level of $5 \%$ with a probability value of 0.0000 and a positive relationship with the coefficient value obtained is 0.137. Furthermore, simultaneously that the BPR credit, GRDP, and unemployment poverty rate in West Java province was $43.3 \%$. While the rest are other supporting factors.

Keywords: Decrease in Poverty Level, increase in BPR credit, Increase in PDRB, Increase in the Open Unemployment Rate

\section{PENDAHULUAN}

Masalah kemiskinan merupakan masalah yang kompleks dan bersifat multidimensional karena sangat erat kaitannya dengan berbagai aspek kehidupan baik sosial, ekonomi, budaya, dan aspek lainnya (Suryawati, 2005; Nurwati, 2008). Kemiskinan menjadi prioritas pembangunan untuk ditangani. Garis Kemiskinan yang dihasilkan hanya menggambarkan kondisi kemiskinan penduduk secara makro dikarenakan sumber data yang dipakai hanya berdasarkan survei (Fahmi, Setyadi, \& Suiro, 2018). Kemiskinan makro ini tidak dapat menggambarkan siapa dan keberadaan penduduk miskin tersebut (Zuhdiyaty \& Kaluge, 2017). Namun demikian, kemiskinan makro dapat digunakan untuk menggambarkan kemiskinan di suatu daerah serta membandingkan kemiskinan antar waktu dan daerah sehingga pemerintah bisa mengambil kebijakan untuk mengatasi kemiskinan tersebut dan juga bisa untuk evaluasi kebijakan penanggulangan kemiskinan.

Dalam Millenium Development Goals (MDGs), kemiskinan menjadi salah satu sasaran utama untuk diperangi negara-negara dunia (Sachs, 2012). Selama ini, pemerintah Indonesia baik di tingkat pusat hingga daerah sudah gencar melancarkan berbagai program untuk mengurangi kemiskinan. Anggaran yang besar digulirkan untuk mengentaskan kemiskinan (Bhinadi, 2017). Seperti kenaikan harga Bahan Bakar Minyak (BBM), kenaikan harga kebutuhan pokok yang tidak bisa dikendalikan, dan lainnya. Kondisi ini terjadi di hampir seluruh wilayah Indonesia termasuk Jawa Barat. Berikut Grafik persentase penduduk miskin Jawa Barat menurut BPS Jawa Barat: 


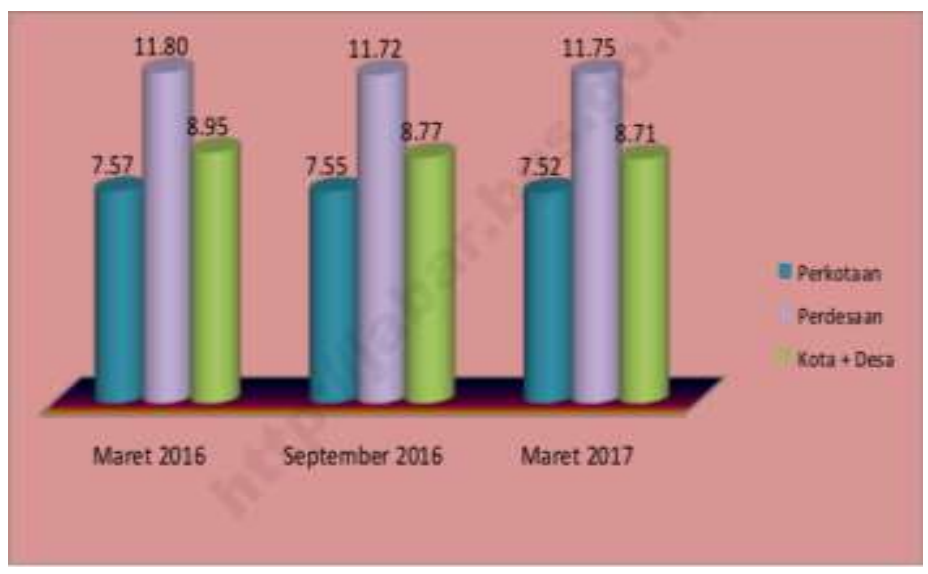

Gambar 1. Grafik Persentase Penduduk Miskin Jawa Barat

Sumber: data Badan pusat statistik (BPS) Jawa Barat (www.bps.go.id)

Dalam data yang dipublikasikan BPS Jawa Barat, dapat dilihat sejauh mana kinerja pemerintah dalam menurunkan angka kemiskinan di tingkat perkotaan, perdesaan, dan kota + desa dalam kurun waktu maret 2016-maret 2017. Pada Maret 2017, persentase penduduk miskin Jawa Barat adalah 8.71\%. Pada September tahun 2016 sebesar $8.77 \%$ dan Maret 2016, 8.95 \%. Sejak tahun 2012 sampai 2015, berturut-turut persentasenya sebesar $9.88 \%, 9.61 \%, 9.18 \%$, dan $9.53 \%$. Dari situ diketahui bahwa penduduk miskin hanya naik pada tahun 2014 ke 2015. Selain itu persentasenya selalu turun.

Kemiskinan masih menjadi persoalan utama di Provinsi Jawa Barat (JABAR) karena tingginya proporsi penduduk miskin dan rendahnya tingkat perkembangan ekonomi, dibandingkan rata-rata di Indonesia. Berbagai upaya penanggulangan kemiskinan telah dilakukan, di antaranya melalui penyediaan layanan keuangan mikro. Pelayanan keuangan mikro merupakan strategi penting yang diyakini dapat membantu membebaskan masyarakat dari kemiskinan. Dalam hal industri perbankan, perilaku kredit mikro juga memiliki karakter yang berbeda dibanding kredit pada umumnya. Menurut Gutiérrez-Nieto, Serrano-Cinca, \& Molinero, (2009) lembaga yang melayani kredit mikro, yaitu microfinance institution (MFI), adalah merupakan kasus khusus dalam dunia keuangan.

Akyuwen, Wijaya, Suthapa, Siregar \& Purwitorosari (2010) mengatakan bahwa selain memberikan andil cukup besar bagi perekonomian nasional, BPR memiliki kedudukan penting dalam mendukung upaya penanggulangan kemiskinan. Hal ini disebabkan cakupan kegiatan BPR yang difokuskan pada usaha mikro dan kecil banyak melibatkan masyarakat miskin maupun masyarakat 
yang kehidupannya dekat dengan kemiskinan (Eviana, 2015).. Sebagaimana diketahui kemiskinan sebagai akibat dari rendahnya pertumbuhan ekonomi, tingkat pertumbuhan penduduk yang tinggi, dan ketidakmerataan distribusi pendapatan. Rini, A. S., \& Sugiharti, L. (2016) mengemukakan faktor penyebab utama kemiskinan adalah karena kurangnya kesempatan kerja dan karena rendahnya produktifitas penduduk miskin. Untuk mengatasi keadaan tersebut, ketika kemiskinan diakibatkan oleh kesempatan kerja yang kurang, maka untuk mengurangi kemiskinan perlu penciptaaan lapangan kerja baru; dan bila kemiskinan terjadi karena rendahnya pendapatan dan rendahnya produktifitas, maka pengurangan kemiskinan dibutuhkan investasi pada sumberdaya manusia dan investasi modal fisik untuk meningkatkan produktifitas pekerja (Tambunan, 2012). Jadi jalan terbaik untuk mengurangi kemiskinan dengan menyediakan kredit mikro kepada penduduk miskin guna menciptakan kesempatan kerja dan meningkatkan pendapatan mereka.

Hal yang lain jika kita melihat dari faktor Produk Domestik Regional Bruto (PDRB) khususnya di provinsi Jawa Barat yang digunakan untuk mengetahui pertumbuhan ekonomi dari tahun ke tahun, sehingga arah perekonomian daerah akan lebih jelas. Produk Domestik Regional Bruto (PDRB) juga indikator untuk mengatur sampai sejauh mana keberhasilan pemerintah dalam memanfaatkan sumber daya yang ada dan dapat digunakan sebagai perencanaan dan pengambilan keputusan yang salah satunya untuk mengurangi jumlah kemiskinan (Cahyono, Almujab, S, S Marten Yogaswara, (2019). Segala kebijakan-kebijakan atau langkah-langkah yang diambil dalam penanggulangan kemiskin berjalan sesuai ekspektasi (Bappenas, 2003). Kemiskinan di Indonesia disebabkan oleh berbagai faktor, yaitu tingkat upah yang masih dibawah standar, tingkat pengangguran yang tinggi, dan pertumbuhan ekonomi yang lambat. seseorang dikatakan miskin apabila dia belum bisa mencukupi kebutuhanya atau belum berpenghasilan (Paramita \& Purbadharmaja, 2015). Arsyad (1997) menyatakan bahwa ada hubungan yang erat sekali antara tingginya tingkat pengangguran dan kemiskinan. Bagi sebagian besar masyarakat, yang tidak mempunyai pekerjaan tetap atau hanya part-time selalu berada diantara kelompok masyarakat yang sangat miskin. Masyarakat yang bekerja dengan bayaran tetap di sektor pemerintah dan swasta 
biasanya termasuk diantara kelompok masyarakat kelas menengah keatas (Sayifullah \& Gandasari, 2016; Mardiana, Militina \& Utary, 2018).

Dengan adanya peningkatan kredit Bank Perkreditan Rakyat (BPR), peningkatan Produk Domestik Regional Bruto (PDRB), dan peningkatan pengangguran terbuka di Jawa Barat yang dapat mengakibatkan tingkat Kemiskinan Kabupaten/Kota di Jawa Barat meningkat, maka sangat penting untuk mengetahui adanya pengaruh peningkatan kredit BPR, peningkatan Produk Domestik Regional Bruto (PDRB), dan peningkatan pengangguran terbuka terhadap kemiskinan Kabupaten/kota di Jawa Barat. Berdasarkan latar belakang tersebut, penelitian ini bertujuan untuk melihat: (1) Seberapa besar peningkatan kredit oleh Bank Perkreditan Rakyat (BPR) berpengaruh terhadap penurunan tingkat kemiskinan di Jawa Barat. (2) Seberapa besar peningkatan produk domestik regional bruto (PDRB) berpengaruh terhadap penurunan tingkat kemiskinan di Jawa Barat. (3) Seberapa besar peningkatan tingkat Pengangguran terbuka berpengaruh terhadap penurunan tingkat kemiskinan di Jawa Barat. (4) Seberapa besar peningkatan kredit oleh Bank Perkreditan Rakyat (BPR), peningkatan produk domestik regional bruto (PDRB), dan peningkatan tingkat pengangguran terbuka berpengaruh secara (simultan) terhadap penurunan tingkat kemiskinan di Jawa Barat.

\section{METODELOGI PENELITIAN}

\section{Desain Penelitian}

Desain penelitian yang digunakan dalam penelitian ini yakni deskriptif dan verifikatif. Sugiyono (2011) menjelaskan penelitian deskriptif adalah penelitian yang berfungsi untuk mendeskripsikan atau memberi gambaran terhadap objek yang diteliti melalui data sampel atau populasi sebagaimana adanya, tanpa melakukan analisis dan membuat kesimpulan yang berlaku untuk umum. Desain penelitian deskriptif ini digunakan untuk menggambarkan peningkatan kredit $\mathrm{BPR}, \mathrm{PDRB}$, peningkatan tingkat pengangguran terbuka, dan penurunan tingkat kemiskinan. Selain itu penelitian verifikatif menurut Arikunto (2006) adalah 
penelitian yang pada dasarnya ingin menguji kebenaran melalui pengumpulan data di lapangan. Pada penelitian ini digunakan untuk melihat pengaruh peningkatan kredit BPR, peningkatan PDRB, dan peningkatan tingkat pengangguran terhadap penurunan tingkat kemiskinan di Jawa Barat pada periode 2010-2016.

\section{Populasi dan Sampel}

Menurut Sugiyono (2010) mengatakan bahwa populasi merupakan "wilayah generalisasi yang terdiri atas objek atau subjek yang mempunyai kualitas dan karakteristik tertentu yang ditetapkan oleh peneliti untuk dipelajari dan kemudian ditarik kesimpulannya". Populasi dari penelitian ini 27 kabupaten/kota di Jawa Barat. Menurut Sugiyono (2010), yang dimaksud dengan sampel adalah "bagian dari jumlah dan karakteristik yang dimiliki oleh populasi tersebut". Sampel adalah bagian dari populasi yang akan dijadikan bahan penelitian. Dalam penelitian ini, sampel yang digunakan adalah data kemiskinan, data kredit BPR, data PDRB, data pengangguran periode 2010-2016 yang telah dipublikasikan oleh BPS dan OJK.

\section{Teknik Pengumpulan Data}

Menurut Sugiyono (2011) pengumpulan data dapat dilakukan dalam berbagai setting, berbagai sumber. Apabila kita dari bermacam sumber, maka pengumpulan data dapat menggunakan sumber primer dan sumber sekunder. Sumber primer adalah sumber data yang langsung memberikan data kepada pengumpul data, dan sumber sekunder merupakan sumber yang tidak langsung memberikan data kepada pengumpul data misalnya, melalui orang lain atau melalui dokumentasi. Sesuai dalam bentuk penelitian kuantitatif. Maka penelitian ini menggunakan data sekunder sehingga teknik pengumpulan data dengan cara menggunakan non participant observasi atau yang diperoleh secara tidak langsung melalui media perantara (diperoleh dan dicatat oleh pihak lain). Data diperoleh dari Badan Pusat Statistik Jawa Barat, Bank Indonesia dan Otoritas Jasa Keuangan. Teknik pengumpulan data yang dilakukan dalam penelitian ini adalah:

\section{Dokumentasi}

Penelitian ini dilakukan dengan mengumpulkan data sekunder yang diperoleh dari website internet BPS yang terkait dengan masalah kemiskinan, PDRB, dan tingkat 
Pengangguran Terbuka dan Bank Indonesia, OJK dengan masalah Pemberian Kredit BPR.

\section{Studi Pustaka}

Studi pustaka merupakan metode pegumpulan data yang dilakukan dengan membaca buku-buku, literatur, jurnal-jurnal, referensi yang berkaitan dengan penelitian ini dan penelitian terdahulu yang berkaitan dengan penelitian yang sedang dilakukan.

\section{Analisis Data}

Uji signifikan merupakan prosedur yang digunakan untuk menguji kesalahan atau kebenaran dari hasil hipotesis nol $\left(\mathrm{H}_{0}\right)$ dari sampel, uji signifikan yang digunakan adalah sebagai berikut:

\section{Koefisien Determinasi $\left(\mathbf{R}^{2}\right)$}

Uji determinasi $\left(\mathrm{R}^{2}\right)$ yaitu mengukur seberapa jauh kemampuan model dalam menerangkan variasi variabel dependen. Nilai koefisien determinasi adalah antara 0 dan 1. Nilai $\left(\mathrm{R}^{2}\right)$ yang kecil bearti kemampuan variabel-variabel bebas dalam menjelaskan variasi variabel terikat amat terbatas. Nilai yang mendekati 1 berarti variabel-variabel independen memberikan hampir semua informasi yang dibutuhkan untuk memprediksi variasi variabel dependen. Secara umum koefisien determinasi untuk data silang (cross section) relatif rendah karena adanya variasi yang besar antara masing-masing pengamatan (Ghozali, 2009).

\section{Uji t-Statistik (Uji Parsial)}

Menurut Ghozali (2009) uji statistik t pada dasarnya menunjukkan seberapa jauh pengaruh satu variabel independen secara individual dalam menerangkan variabel dependen. Pengujian dilakukan dengan menggunakan signifikan level 0,05 ( $\alpha=$ 5\%). Penerimaan atau penolakan hipotesis dilakukan dengan kriteria:

1) Jika nilai signifikan > 0,05 maka hipotesis ditolak (koefisien regresi tidak signifikan). Ini berarti secara parsial variabel independen tidak mempunyai pengaruh secara signifikan terhadap variabel dependen.

2) Jika nilai signifikan $\leq 0,05$ maka hipotesis diterima (koefisien regresi signifikan). Ini berarti secara parsial variabel independen tersebut mempunyai pengaruh yang signifikan terhadap variabel dependen.

\section{Uji F-Statistik (Uji Simultan)}


Uji F ini dilakuakan untuk mengetahui apakah dalam model regresi variabel Kredit BPR, PDRB, dan pengangguran secara simultan berpengaruh signifikan terhadap kemiskinan di Jawa Barat dengan tingkat keyakinan 95\% $(\alpha=5 \%)$. Uji F ditunjukan untuk mengukur hubungan keseluruhan antara koefisien regresi dari variabel bebas terhadap variabel terikat. Pengujian hipotesis adalah:

$\mathrm{H}_{0}: \beta_{1}=\beta_{2}=\beta_{3} \ldots \beta_{\mathrm{n}}=0$, berarti variabel bebas $(\mathrm{X})$ tidak meiliki pengaruh signifikan secara simultan terhadap variabel terikat (Y).

$\mathrm{H}_{\mathrm{a}}: \beta_{1}=\beta_{2}=\beta_{3} \ldots \beta_{\mathrm{n}} \neq 0$, bearti variabel bebas $(\mathrm{X})$ memiliki pengaruh signifikan secara simultan terhadap variabel terikat $(\mathrm{Y})$.

Untuk menguji hipotesis secara simultan digunakan statistik $\mathrm{F}\left(\mathrm{F}_{\text {test }}\right)$. Rumus yang digunakan untuk statistik F adalah:

$$
F=\frac{\text { Mean Square Regression }}{\text { Mean Square Error }}
$$

Jika $F_{\text {hitung }}<\mathrm{F}_{\text {tabel}}$, maka $\mathrm{H}_{0}$ diterima dan $\mathrm{H}_{1}$ ditolak, dan jika $\mathrm{F}_{\text {hitung }}>\mathrm{F}_{\text {tabel }}$, maka $\mathrm{H}_{1}$ diterima dan $\mathrm{H}_{0}$ ditolak.

\section{HASIL PENELITIAN DAN PEMBAHASAN}

\section{Hasil Penelitian}

Untuk mengetahui signifikan atau tidaknya suatu pengaruh dari variabelvariabel bebas secara parsial atas suatu variabel tidak bebas digunakan uji t. Berdasarkan hasil perhitungan diperoleh data yang terlihat pada tabel 1.

Tabel 1 Pengujian Hipotesis Secara Parsial (Uji t)

\begin{tabular}{ccccc}
\hline Variabel & Hasil & t-statistic & Prob & Sign \\
\hline Kredit BPR & $(-) 0.144$ & $(-) 7.940$ & 0.0000 & Signifikan \\
PDRB & $(-) 0.024$ & $(-) 1.653$ & 0.1016 & Tidak signifikan \\
Pengangguran & $(+) 0.137$ & 8.955 & 0.0000 & Signifikan \\
\hline
\end{tabular}

Uji parsial dilakukan untuk menguji pengaruh variabel-variabel independen terhadap variabel dependen. Berdasarkan tabel di atas diperoleh hasil bahwa secara parsial, kredit BPR $\left(\mathrm{X}_{1}\right)$ memiliki pengaruh yang signifikan terhadap kemiskinan (Y). Hal ini dapat di lihat dari nilai t-staistic -7.940, nilai ini lebih 
besar dari nilai tabel $-1,981$ dengan arah hubungan yang negatif. Hal ini sejalan dengan nilai probabilitas yang berada dibawah nilai error yang dapat ditoleransi yaitu 5\% $(0.0000<0.05)$ tingkat kepercayaan 95\%, artinya semakin tinggi kredit BPR yang diberikan maka akan menurunkan tingkat kemiskinan dengan pengaruh yang signifikan.

Selain itu untuk produk domestik regional bruto tidak memiliki pengaruh yang signifikan terhadap kemiskinan. Hal ini dapat dilihat dari nilai $t$-statistic 1.653, nilai ini lebih kecil dari nilai $t_{\text {tabel }}-1,981$ dengan arah hubungan yang negatif. Hal ini sejalan dengan nilai probabilitas yang berada diatas nilai error yang dapat ditoleransi yaitu 5\% (0.1016>0.05) tingkat kepercayaan 95\%, artinya semakin tinggi produk domestik regional Bruto di suatu daerah maka akan menurunkan tingkat kemiskinan dengan pengaruh yang tidak signifikan.

Sedangkan untuk tingkat pengangguran terbuka memiliki pengaruh yang signifikan terhadap kemiskinan. Hal ini dapat dilihat dari nilai $t$-statistic 8.955, nilai ini lebih besar dari nilai $t_{\text {tabel }}-1,981$ dengan arah hubungan yang positif. Hal ini sejalan dengan nilai probabilitas yang berada diatas nilai error yang dapat ditoleransi yaitu $5 \%(0.0000>0.05)$ tingkat kepercayaan $95 \%$, artinya semakin tinggi tingkat pengangguran di suatu daerah maka akan meningkatkan kemiskinan dengan pengaruh yang signifikan.

\section{Pengujian Hipotesis Secara Simultan (Uji F)}

Untuk mengetahui signifikan atau tidaknya suatu pengaruh dari variabelvariabel bebas secara bersama-sama atas suatu variabel tidak bebas digunakan uji F atau pengujian secara simultan. Dengan kata lain, akankah kedua variabel bebas secara bersama-sama mampu mempengaruhi variabel terikat dengan signifikan. Hasil uji F berdasarkan pengolahan Eviews 8.0 disajikan pada tabel berikut :

Tabel 2. Pengujian Hipotesis Secara Simultan (Uji F)

\begin{tabular}{cc}
\hline F- Statistic & 43.22851 \\
\hline Prob (F-Statistic) & $\mathbf{0 . 0 0 0 0 0 0}$ \\
\hline ari tabel diatas, diperoleh nilai Prob. F hitung sebesar 0,000 . Oleh karena \\
Prob. F hitung $(0,000)<0,05$, maka $\mathrm{H}_{0}$ ditolak. Dengan demikian dapat
\end{tabular}

nilai Prob. F hitung $(0,000)<0,05$, maka $\mathrm{H}_{0}$ ditolak. Dengan demikian dapat 
disimpulkan bahwa secara simultan terdapat pengaruh yang signifikan dari variabel kredit $\mathrm{BPR}\left(\mathrm{X}_{1}\right)$, produk domestik regional bruto $\left(\mathrm{X}_{2}\right)$, dan pengangguran $\left(\mathrm{X}_{3}\right)$ terhadap Kemiskinan $(\mathrm{Y})$.

\section{Analisis Koefisien Determinasi $\left(\mathbf{R}^{2}\right)$}

Untuk mengetahui besarnya pengaruh kredit BPR, produk domestik regional bruto, dan pengangguran secara bersama-sama terhadap kemiskinan, digunakan koefisien determinasi. Jika uji simultan digunakan unutk menguji hipotesis secara keseluruhan, maka koefisien determinasi digunakan untuk menghitung besaran pengaruh dari kedua variabel bebasnya, yaitu variabel Kredit BPR, Produk Domestik Regional Bruto, dan Pengangguran. Besaran pengaruh ini berkisar dari interval 0 hingga 1 atau 0\% hingga 100\%. Tabel 3 di bawah ini memperlihatkan hasil perhitungan koefisien determinasi dari 20 data panel yang digunakan.

Tabel 3 Analisis Koefisien Determinasi

\begin{tabular}{|l|r|}
\hline R-squared & $\mathbf{0 . 8 9 2 4 3 1}$ \\
\hline Adjusted R-squared & 0.871787 \\
\hline
\end{tabular}

Berdasarkan hasil output Eviews 8.0 di atas, diperoleh nilai $R$-squared sebesar 0.893. Hal ini menunjukkan bahwa kontribusi kredit BPR $\left(\mathrm{X}_{1}\right)$, produk domestik regional bruto $\left(\mathrm{X}_{2}\right)$, dan pengangguran $\left(\mathrm{X}_{3}\right)$ terhadap kemiskinan $(\mathrm{Y})$ adalah sebesar 89,3\% sedangkan sisanya sebesar 10,7\% merupakan kontribusi variabel lain selain variabel bebas yang diteliti.

\section{Pembahasan}

\section{Pengaruh Peningkatan Kredit BPR terhadap Penurunan Tingkat Kemiskinan}

Dari hasil regresi yang dihasilkan dalam penelitian ini, menunjukan bahwa variabel kredit BPR menunjukan tanda negatif dan berpengaruh secara signifikan terhadap kemiskinan di provinsi Jawa Barat. Untuk variabel kredit BPR $\left(\mathrm{X}_{1}\right)$ diperoleh nilai t hitung sebesar -7.940. Karena thitung (-7.940) > t tabel (-1,981), maka $\mathrm{H}_{0}$ diolak. Hasil tersebut sesuai dengan teori dan penelitian terdahulu yang menjadi landasan teori dalam penelitian ini. Kredit yang diberikan oleh BPR telah menyentuh masyarakat yang marginal (poor people). Kredit yang diberikan telah 
tepat sasaran, dilihat dari peruntukannnya kredit yang di salurkan masyarakat menengah kebawah dan mikro digunakan untuk tujuan produktif yang tentunya akan meningkatkan pendapatan, sehingga akan meningkatkan kesejahteraaan masyarakat. Ini semua tidak lepas dari peran BPR yang sangat hati-hati dalam memberikan kredit kepada calon debitur. Pendekatan yang dipakai oleh BPR dalam rangka mengetaskan kemiskinan tentunya akan berbeda-beda sesuai dengan tingkatan yang dimiliki, sehingga sasaran yang dicapai tepat sasaran. Pendekatan bagi kelompok masyarakat yang sangat miskin (the extreme poor) dengan pendekatan langsung berupa program pangan dan penciptaan lapangan kerja baru. Sedangkan kelompok yang miskin dengan penghasilan rendah menggunakan pendekatan tidak langsung seperti penciptaan iklim yang kondusif bagi pengembangan usaha mikro dan UKM, terbentuknya lembaga pelatihan dan konsultasi BPR, pengembangan berbagai jenis pinjaman yang dapat mempermudah akses kelompok tersebut, upaya yang dilakukan oleh BPR berdampak pada penurunan tingkat kemiskinan di Jawa Barat.

\section{Pengaruh Peningkatan Produk Domestik Regional Bruto terhadap Penurunan Tingkat Kemiskinan}

Produk domestik regional bruto memiliki peran penting dalam pertumbuhan ekonomi. Variabel PDRB tidak signifikan terhadap kemiskinan di Jawa Barat. Untuk variabel produk domestik regional bruto $\left(\mathrm{X}_{2}\right)$ diperoleh nilai $\mathrm{t}_{\text {hitung }}$ sebesar 1.653. Oleh karena $t_{\text {hitung }}(-1.653)<\mathrm{t}_{\text {tabel }}(-1,981)$, maka $\mathrm{H}_{0}$ diterima, dan menunjukkan tanda negatif. Hasil tersebut sesuai dengan teori dan penelitian terdahulu yang menjadi landasan teori dalam penelitian ini. Untuk meningkatkan peran pemerintah daerah dalam mengelola PDRB yang lebih baik, perlu ditingkatkan secara berkesinambungan sehingga tingkat kemiskinan di Jawa Barat dapat menurun pada setiap periodenya. Pihak pemerintah daerah perlu memberikan perhatian khusus dalam hal PDRB sebagai skala prioritas dalam upaya menanggulangi tingkat kemiskinan di Jawa Barat, dengan meningkatkan pertumbuhan ekonomi melalui berbagai upaya mendorong jumlah penduduk miskin di Jawa Barat. Khususnya dalam memastikan dan mendistribusikan manfaat pertumbuhan yang di dapatkan dari sektor-sektor dimana penduduk miskin bekerja. 
Distribusi yang adil dan merata dari hasil pertumbuhan PDRB akan berdampak pada terciptanya pembangunan di segala sektor lapangan pekerjaaan dan berpotensi mengurangi tingkat kemiskinan. Kurangnya PDRB akan berdampak pada kesejahteraan pada masalah-masalah sosisal lainnya dari tingkat kemiskinan. Pertumbuhan PDRB harus menyebar di setiap golongan, termasuk golongan penduduk miskin. Oleh karena itu, pertumbuhan PDRB setiap sektor sangatlah penting dalam mengurangi dan menanggulangi tingkat kemiskinan di Jawa Barat. Dapat disimpulkan bahwa produk domestik regional bruto $\left(\mathrm{X}_{2}\right)$ secara parsial tidak memiliki pengaruh signifikan terhadap kemiskinan (Y). Hasil penelitian menunjukan bahwa produk domestik regional bruto memiliki koefisien negatif yang berarti semakin tinggi produk domestik regional bruto, maka akan berdampak pada penurunan tingakat kemiskinan dengan pengaruh yang tidak signifikan. Sebaliknya, samakin menurunnya produk domestik regional bruto maka akan berdampak pada peningkatan kemiskinan dengan pengaruh yang tidak signifikan.

\section{Pengaruh Tingkat Pengangguran Terbuka terhadap Penurunan Tingkat Kemiskinan}

Hasil regresi yang dihasilkan dalam penelitian ini, menunjukan bahwa variabel tingkat pengangguran signifikan terhadap kemiskinan di Jawa Barat. Untuk variabel Tingkat Pengangguran $\left(\mathrm{X}_{3}\right)$ diperoleh nilai t hitung sebesar 8.955 Karena t hitung $(8.955)>\mathrm{t}$ tabel $(1,981)$, maka $\mathrm{H}_{0}$ ditolak, dan menunjukan tanda positif. Hasil tersebut sesuai dengan teori dan penelitian terdahulu yang menjadi landasan teori dalam penelitian ini. Dan diharapkan pemerintah Provinsi Jawa Barat lebih banyak lagi melakukan perluasan kesempatan kerja dengan cara mendirikan industry-industri baru yang bersifat padat karya serta menggalakkan sektor informal, seperti homeindustry. Karena pengangguran dalam penelitian ini menggunakan pengangguran terbuka, yang mana didalamnya terdapat golongan masyarakat yang sedang mencari pekerjaan dan sedang dalam tahap menyiapkan usaha atau mendapat pekerjaan tetapi belum mulai bekerja yang dimasukkan dalam golongan pengangguran. Sehingga pentingnya perluasan kesempatan kerja yang bersifat padat karya dan peningkatan sektor informal untuk menurunkan tingkat kemiskinan di Jawa Barat 
Oleh karena itu, dapat disimpulkan bahwa tingkat pengangguran terbuka $\left(\mathrm{X}_{3}\right)$ secara parsial memiliki pengaruh signifikan terhadap Kemiskinan (Y). Hasil penelitian menunjukan bahwa tingkat pengangguran terbuka memiliki koefisien positif yang berarti semakin tinggi tingkat pengangguran maka akan berdampak pada peningkatan tingakat kemiskinan dengan pengaruh yang signifikan. Sebaliknya, samakin rendah tingkat pengangguran maka akan berdampak pada penurunan tingkat kemiskinan dengan pengaruh yang signifikan.

\section{Pengaruh Kredit BPR dan Produk Domestik Regional Bruto terhadap Kemiskinan}

Secara bersama-sama atau simultan terdapat pengaruh signifikan antara kredit BPR, produk domestik regional bruto, pengangguran terhadap kemiskinan. Berdasarkan hasil perhitungan sebelumnya dapat dilihat bahwa nilai probabilitas $F$-statistic bernilai 0,000. Karena nilai prob $F$-statistic $0,000<0,05$ maka $\mathrm{H}_{0}$ ditolak, artinya secara bersama-sama kredit BPR, produk domestik regional bruto, dan pengangguran berpengaruh signifikan terhadap kemiskinan. Apabila dibandingkan antara kredit BPR, produk domestik regional bruto, dan pengangguran pengaruh kontribusi yang paling besar adalah Tingakat Pengangguran, Kredit BPR kemudian Produk Domestik Regional Bruto (PDRB). Hal ini dapat dilihat dari nilai $t$-statistic masing-masing variabel bahwa $t$-statistic tingkat pengangguran dan kredit BPR lebih besar jika dibandingkan t-statistic PDRB.

\section{KESIMPULAN}

Berdasarkan temuan hasil penelitian dan analisis seperti yang telah diuraikan diatas, maka dapat dikemukakan sbahwa lembaga keuangan mikro yang tujuannya bukan memaksimumkan profit, tetapi lebih mengutamakan pada memperkerjakan tenaga kerja yang lebih banyak, memberikan pelayanan yang lebih pada kelompok miskin, dan beberapa tujuan lain yang sifatnya lebih sosial. Dalam hal pengembangan dan penguatan kelembagaan, Untuk memperkuat kapasitas kelembagaan sebaiknya Bank Perkreditan Rakyat (BPR) diharapkan dapat meningkatkan penyaluran kredit kepada usaha mikro. Hal tersebut dilakukan dengan memberikan bantuan pelatihan dan konsultasi BPR serta mengkaji kemungkinan menetapkan standar teknologi informasi bagi BPR. Dalam 
rangka mengembangkan infrastruktur perbankan dan terus menyempurnakan sistem informasi debitur guna membantu bank.

Untuk menekan tingkat kemiskinan, pemerintah daerah hendaknya meningkatkan PDRB secara merata yang nantinya akan menurunkan angka kemiskinan di daerahnya. Meningkatkan PDRB berarti meningkatkan pertumbuhan ekonomi. Pertumbuhan ekonomi merupakan salah satu kunci untuk mengurangi kemiskinan, karena pertumbuhan meningkatkan kebutuhan akan tenaga kerja yang artinya terbukanya lapangan pekerjaan yang baru. Dengan bekerja pendapatan meningkat yang artinya tingkat kesejahteraan meningkat.

Perlu dilakukan penelitian lanjutan dengan menambah variabel-variabel yang sekiranya berpengaruh terhadap kemiskian, diharapkan penelitian selanjutnya dapat lebih terfokus pada wilayah yang cakupannya lebih kecil agar lebih dapat terfokus secara khusus di suatu wilayah yang ada di Indonesia terutama daerah-daerah tertinggal.

\section{DAFTAR PUSTAKA}

Akyuwen, R., Wijaya, K., Suthapa, I. D. G., Siregar, F. M., \& Purwitorosari, P. 2010. Teori dan praktek keuangan mikro di Indonesia. Sekolah Pascasarjana, Universitas Gadjah Mada.

Arikunto, S. 2006. Prosedur Penelitian: Suatu Pendekatan Praktik. Jakarta: Rineka Cipta

Arsyad, L. 1997. Ekonomi Pembangunan, Edisi Ketiga. Yogyakarta: BP STIE YKPN

Bhinadi, A. 2017. Penanggulangan kemiskinan dan pemberdayaan masyarakat. Deepublish.

Badan Pusat Statistik. 2016. "Produk Domestik Regional Bruto". Diakses: htpp://www.bps.go.id

Bappenas. 2003. Sistem data dan penentuan sasaran (targeting) dalam penanggulangan kemiskinan. Bappenas.

Cahyono, Almujab, S, S Marten Yogaswara. 2019. Analisis Produk Domestik Regional Bruto (Pdrb) Dan Pertumbuhan Ekonomi Kabupaten Subang Tahun 2017/2018. OIKOS: Jurnal Kajian Pendidikan Ekonomi dan Ilmu Ekonomi, Volume 3, Nomor 1, Februari 2019 
Eviana, E. 2015. Program Penanggulangan Kemiskinan Berbasis Pemberdayaan Usaha Ekonomi Mikro dan Kecil (Studi Pemberdayaan Home Industry Sambel Pecel di Kota Madiun). Jurnal Administrasi Publik, 3(8), 12851289.

Fahmi, G. R. A., Setyadi, S., \& Suiro, U. 2018. Analisis Strategi Penanggulangan Kemiskinan Di Provinsi Banten. Jurnal Ekonomi-Qu, 8(2).

Ghazali, I. 2009. Aplikasi Analisis Multivariate Program Edisi Ketiga. Semarang: BP Undip

Gutiérrez-Nieto, B., Serrano-Cinca, C., \& Molinero, C. M. 2009. Social efficiency in microfinance institutions. Journal of the operational research society, 60(1), 104-119.

Mardiana, M., Militina, T., \& Utary, A. R. 2018. Analisis pengaruh pengeluaran pemerintah daerah sektor pendidikan dan kesehatan serta infrastruktur terhadap tingkat pengangguran serta tingkat kemiskinan. INOVASI, 13(1), 50-60.

Nurwati, N. 2008. Kemiskinan: Model Pengukuran, Permasalahan dan Alternatif Kebijakan. Jurnal Kependudukan Padjadjaran, 10(1), 1.

Paramita, A. I. D., \& Purbadharmaja, I. P. 2015. Pengaruh Investasi dan Pengangguran terhadap Pertumbuhan Ekonomi serta Kemiskinan di Provinsi Bali. E-Jurnal Ekonomi Pembangunan Universitas Udayana, 4(10), 44574.

Rini, A. S., \& Sugiharti, L. 2016. Faktor-Faktor Penentu Kemiskinan di Indonesia: Analisis Rumah Tangga. Jurnal ilmu ekonomi Terapan, 1(2).

Sachs, J. D. 2012. From millennium development goals to sustainable development goals. The Lancet, 379(9832), 2206-2211.

Sugiyono. 2010. Metode Penelitian Bisnis. Bandung: CV Alfabeta

Sugiyono. 2011. Metode penelitian Kuantitatif Kualitatif dan R\&D. Bandung: Grafindo Persada

Suryawati, C. 2005. Memahami kemiskinan secara multidimensional. Jurnal Manajemen Pelayanan Kesehatan, 8(03).

Sayifullah, S., \& Gandasari, T. R. 2016. Pengaruh Indeks Pembangunan Manusia Dan Pengangguran Terhadap Kemiskinan Di Provinsi Banten. Jurnal Ekonomi-Qu, 6(2).

Tambunan, T. T. 2012. Peran usaha mikro dan kecil dalam pengentasan kemiskinan di daerah. Jurnal Bina Praja: Journal of Home Affairs Governance, 4(2), 73-92. 
Zuhdiyaty, N., \& Kaluge, D. 2017. Analisis Faktor-Faktor Yang Mempengaruhi Kemiskinan Di Indonesia Selama Lima Tahun Terakhir. Jurnal Ilmiah Bisnis dan Ekonomi Asia, 11(2), 27-31 